\title{
1 Paratype: A genotyping framework and an open-source tool for Salmonella
}

\section{Paratyphi A}

3 Arif M. Tanmoy ${ }^{1,2^{*}}$, Yogesh Hooda ${ }^{1,3^{*}}$, Mohammad S. I. Sajib ${ }^{1,4}$, Kesia E. da Silva ${ }^{5}$, Junaid

4 Iqbal $^{6}$, Farah N. Qamar ${ }^{6}$, Stephen P. Luby ${ }^{5}$, Gordon Dougan ${ }^{7}$, Zoe A. Dyson ${ }^{7,8,9,12}$, Stephen

5 Baker $^{8}$, Denise O. Garrett ${ }^{10}$, Jason R. Andrews ${ }^{5}$, Samir K. Saha ${ }^{1,11, \$}$, Senjuti Saha ${ }^{1, \$, \#}$

$7 \quad{ }^{1}$ Child Health Research Foundation, Dhaka, Bangladesh. arif.tanmoy@ chrfbd.org,

8 yhooda@chrfbd.org, saiful.sajib@chrfbd.org, samir@chrfbd.org, senjutisaha@chrfbd.org

$9 \quad{ }^{2}$ Department of Medical Microbiology and Infectious Diseases, Erasmus University Medical

10 Center, Rotterdam, the Netherlands.

$11{ }^{3}$ MRC-Laboratory Molecular Biology, Cambridge, UK.

$12{ }^{4}$ Institute of Biodiversity, Animal Health and Comparative Medicine, University of Glasgow,

13 Glasgow, UK.

$14{ }^{5}$ Division of Infectious Diseases and Geographic Medicine, Stanford University School of

15 Medicine, Stanford, California, USA. kesiaeds@stanford.edu, sluby@ stanford.edu,

16 jandr@stanford.edu

$17{ }^{6}$ Department of Paediatrics and Child Health, Aga Khan University, Karachi, Pakistan.

18 junaid.iqbal@aku.edu, farah.qamar@aku.edu

$19{ }^{7}$ Wellcome Trust Sanger Institute, Hinxton, Cambridge CB10 1SA, UK.

20 gd312@medschl.cam.ac.uk

$21{ }^{8}$ Cambridge Institute of Therapeutic Immunology and Infectious Disease, Department of

22 Medicine, University of Cambridge, Cambridge, United Kingdom.

23 sgb47@medschl.cam.ac.uk

$24{ }^{9}$ Department of Infection Biology, London School of Hygiene and Tropical Medicine,

25 London, UK. Zoe.Dyson@1shtm.ac.uk

$26{ }^{10}$ Applied Epidemiology Team, Sabin Vaccine Institute, Washington, DC, USA.

27 Denise.Garrett@Sabin.org 
medRxiv preprint doi: https://doi.org/10.1101/2021.11.13.21266165; this version posted November 28, 2021. The copyright holder for this preprint (which was not certified by peer review) is the author/funder, who has granted medRxiv a license to display the preprint in perpetuity. All rights reserved. No reuse allowed without permission.

$28{ }^{11}$ Department of Microbiology, Bangladesh Institute of Child Health, Dhaka Shishu Hospital,

29 Dhaka, Bangladesh.

$30 \quad{ }^{12}$ Department of Infectious Diseases, Central Clinical School, Monash University,

31 Melbourne, Victoria 3004, Australia.

32

$33 *{ }^{\$}$ Equal contribution;

$34{ }^{\#}$ Corresponding author

35

36

37

38

39

40

41

42

43

44

45

46

47

48

49

50 
medRxiv preprint doi: https://doi.org/10.1101/2021.11.13.21266165; this version posted November 28, 2021. The copyright holder for this

\section{Abstract}

52 Background: Salmonella enterica serovar Paratyphi A (Salmonella Paratyphi A) is the

53 primary causative agent of paratyphoid fever, which is responsible for an estimated 3.4

54 million infections annually. However, little genomic information is available on population

55 structure, antimicrobial resistance (AMR), and spatiotemporal distribution of the pathogen.

56 With rising antimicrobial resistance and no licensed vaccines, genomic surveillance is

57 important to track the evolution of this pathogen and monitor transmission.

58 Results: We performed whole-genome sequencing of 817 Salmonella Paratyphi A isolates

59 collected from Bangladesh, Nepal, and Pakistan and added publicly available 562 genomes to

60 build a global database representing 37 countries, covering 1917-2019. To track the evolution

61 of Salmonella Paratyphi A, we used the existing lineage scheme, developed earlier based on a

62 small dataset, but certain sub-lineages were not homologous, and many isolates could not be

63 assigned a lineage. Therefore, we developed a single nucleotide polymorphism based

64 genotyping scheme, Paratype, a tool that segregates Salmonella Paratyphi A into three

65 primary and nine secondary clades, and 18 genotypes. Each genotype has been assigned a

66 unique allele definition located on a conserved gene. Using Paratype, we identified genomic

67 variation between different sampling locations and specific AMR markers, and mutations in

68 the O2-polysaccharide synthesis locus, a candidate for vaccine development.

69 Conclusions: This large-scale global analysis proposes the first genotyping tool for

70 Salmonella Paratyphi A. Paratype has already been released (https://github.com/CHRF-

71 Genomics/Paratype) as an open-access, command-line tool and is being adopted for large

72 scale genomic analysis. This tool will assist future genomic surveillance and help inform

73 prevention and treatment strategies. 
medRxiv preprint doi: https://doi.org/10.1101/2021.11.13.21266165; this version posted November 28, 2021. The copyright holder for this preprint (which was not certified by peer review) is the author/funder, who has granted medRxiv a license to display the preprint in perpetuity. All rights reserved. No reuse allowed without permission.

75 Keywords: Salmonella Paratyphi A; Paratyphoid fever; Paratyphi A genotyping; Genomics;

76 Antimicrobial resistance; Global analysis; Epidemiology; Enteric fever; Neglected tropical

77 disease.

78

79

80

81

82

83

84

85

86

87

88

89

90

91

92

93

94

95 
medRxiv preprint doi: https://doi.org/10.1101/2021.11.13.21266165; this version posted November 28, 2021. The copyright holder for this

\section{Background}

97 Paratyphoid fever, caused by Salmonella enterica subspecies enterica serovar Paratyphi A

98 (Salmonella Paratyphi A) is a systemic febrile illness that affects an estimated 3.4 million

99 people each year, and causes 19,100 deaths globally [1]. The disease is clinically

100 indistinguishable from typhoid fever, caused by Salmonella enterica subspecies enterica

101 serovar Typhi (Salmonella Typhi). Much like typhoid, paratyphoid fever is also endemic in

102 many low- and middle-income countries of South Asia and Sub-Saharan Africa, due to fecal

103 contamination of water, food and the environment. However, barring a few countries (e.g.,

104 China, Myanmar), paratyphoid fever is usually less prevalent than typhoid fever $[2,3]$.

105 Salmonella Paratyphi A continues to be an inadequately studied pathogen [4] hampering the

106 implementation of evidence-based policies for the treatment and prevention of paratyphoid

107 fever.

Relative to Salmonella Typhi, little genomic information is available on population structure, antimicrobial resistance (AMR), and spatiotemporal distribution of Salmonella Paratyphi A.

The first Salmonella Paratyphi A genome was published in 2004 and had a size of $4.5 \mathrm{Mb}$, with 4,200 genes. To determine the global diversity of Salmonella Paratyphi A isolates,

Bayesian analysis was conducted on a set of 149 Salmonella Paratyphi A genomes, which

years prior to differentiating into at least seven distinct lineages (A to G) which have

circulated globally [5]. Whole genome sequencing was also used to characterize clonal

paratyphoid outbreaks in Cambodia [6] and China [7] and further extend the lineage scheme 
medRxiv preprint doi: https://doi.org/10.1101/2021.11.13.21266165; this version posted November 28, 2021. The copyright holder for this

preprint (which was not certified by peer review) is the author/funder, who has granted medRxiv a license to display the preprint in perpetuity.

All rights reserved. No reuse allowed without permission.

121 from a specific geographical location or provide no information on antimicrobial resistance

122 markers, potential vaccine targets, and other virulence factors.

124 To address this data gap, we performed whole-genome sequencing of 817 Salmonella

125 Paratyphi A isolates collected from Bangladesh, Nepal, and Pakistan and combined them

126 with whole-genome sequence data of another 562 isolates reported in the literature to build a

127 global database of 1,379 Salmonella Paratyphi A isolates. To track the evolution of

128 Salmonella Paratyphi A over a century, we used the existing lineage scheme and found that

129 certain sub-lineages were not homologous, and many isolates could not be assigned a specific

130 lineage. This motivated us to develop a single nucleotide polymorphism (SNP) based

131 genotyping scheme, called Paratype. The scheme is phylogenetically informative and

132 successfully segregates the global population structure into three primary, seven secondary,

133 and 18 distinct subclades/genotypes. We also identified the specific antimicrobial resistance

134 genes, mutations, and plasmids present in Salmonella Paratyphi A genomes and correlated

135 these with the different genotypes.

$137 \quad$ Results

138 Whole-genome sequencing and compilation of global Salmonella Paratyphi A genomes

139 The Child Health Research Foundation (CHRF) has been conducting typhoid and

140 paratyphoid fever surveillance in Bangladesh since 1999 and has generated a biobank of

141 1,123 Salmonella Paratyphi A isolates from 1999-2018 [10-12]. We selected 528 of these

142 isolates, covering all age groups, years of isolation, and hospitalization status

143 (hospitalized/out-patient), and performed whole-genome sequencing on these isolates

144 (Additional file 1: Table S1). Of these, 180 Salmonella Paratyphi A isolates were collected as 
medRxiv preprint doi: https://doi.org/10.1101/2021.11.13.21266165; this version posted November 28, 2021. The copyright holder for this

part of the Surveillance of Enteric Fever in Asia Project (SEAP, 2014 - 2019) study, a multicountry international effort to better understand the epidemiology and impact of enteric fever in South Asia [13]. In addition to Bangladesh, 133 isolates were sequenced from the SEAP study conducted in Pakistan, and 156 from Nepal.

To contextualize these genomes, we conducted a literature search to compile all publicly available Salmonella Paratyphi A genomes (for which raw reads were available) to build a database of 560 additional isolates from 10 studies (Additional file 1: Table S2). Two reference genomes (ATCC 9150 and AKU_12601) were also included. The largest dataset consisted of 254 isolates, published by Public Health England as part of their Salmonella surveillance $[8,14] ; 164$ of these isolates were linked to travel, most commonly to South Asia. In our study, we assigned these isolates to the countries where the patient acquired the infection. Our final data, including the genomes we sequenced, consisted of a total of 1,379 isolates from 37 different countries, spanning over 103 years - 1917 to 2019. Most of the isolates $(1,112 / 1,379 ; 81 \%)$ were from countries in South Asia (541 from Bangladesh, 268 from Nepal, 187 from Pakistan and 115 from India). South Asian countries also bear a disproportionately high burden of paratyphoid fever; of the estimated 3.4 million global paratyphoid infections in 2019, 2.8 (82\%) million are estimated to have occurred in South Asia [1].

Following assembly from raw reads, the pan-genome analysis identified 6,983 genes, of which 4,114 (59\% of all genes) were conserved in more than $95 \%$ of isolates (Additional file 1: Figure S1). The average genome size was $4.5 \mathrm{Mb}$ with $\sim 4,300$ genes, and the pan genome does not appear to be closed (decay parameter, alpha $=0.67$ ). Overall, 2,550 genes were 
medRxiv preprint doi: https://doi.org/10.1101/2021.11.13.21266165; this version posted November 28, 2021. The copyright holder for this

preprint (which was not certified by peer review) is the author/funder, who has granted medRxiv a license to display the preprint in perpetuity.

All rights reserved. No reuse allowed without permission.

found to be present in less than $15 \%$ of isolates, and these included genes often found in prophages and other mobile regions, and genes encoding adhesins, antimicrobial resistance markers, and several hypothetical proteins.

\section{Genotyping scheme for Salmonella Paratyphi A}

To investigate the genomic diversity of Salmonella Paratyphi A, we identified 8,346 single nucleotide polymorphisms (SNPs) in the 1,379 isolates. These were used in RAxML [15] to generate a Maximum-likelihood phylogenetic tree of the global collection of Salmonella Paratyphi A isolates (Figure 1). A previously reported lineage scheme, proposed for Salmonella Paratyphi A by Zhou et al. [5] and extended by subsequent studies $[6,7,9,16,17]$ was overlaid on the RAxML tree. This highlighted the insufficiency of the current lineage scheme to fully capture the diversity of Salmonella Paratyphi A present. First, while the isolates from lineages B \& D - G clustered together, several isolates previously assigned to lineages $\mathrm{A}$ and $\mathrm{C}$ in the scheme did not. Second, some sequences belonged to clades that diverged from isolates before the exitance of the most recent common ancestor for lineages $\mathrm{A}$ and $\mathrm{B}$, indicating that these isolates should be considered to be in a different lineage. This was not surprising considering that when this scheme was devised, there were limited number of sequenced Salmonella Paratyphi A genomes available, particularly from South Asia.

To build a genotyping scheme based on a larger number of representative samples, first, we used fastBAPS [18] to generate a potential list of clusters in the RAxML tree (Additional file 1: Figure S2). Next, we selected a set of 315 isolates that included two isolates per year for all fastBAPS clusters selected randomly and performed phylodynamic analysis using the Bayesian Evolutionary Analysis by Sampling Trees (BEAST) software [19] (Figure 2). Based 
medRxiv preprint doi: https://doi.org/10.1101/2021.11.13.21266165; this version posted November 28, 2021. The copyright holder for this

on these analyses, we devised a genotyping scheme with three primary clades, nine secondary clades, and 18 genotypes that have circulated globally in the last 100 years.

To aid further genomic epidemiological studies, we identified 18 additional alleles

(Additional file 1: Table S3) that are unique to each of the 18 Salmonella Paratyphi A

genotypes. These alleles were present in conserved genes involved in essential cellular

functions such as protein synthesis, DNA replication, or metabolism. Identification of these genotype-specific alleles allowed us to write a Python script - "Paratype" - that assigns genotypes to Salmonella Paratyphi A genomes using fastq, bam, or vef files obtained during whole-genome sequencing and variant calling. The Paratype software tool (available at: https://github.com/CHRF-Genomics/Paratype/) has $100 \%$ sensitivity and specificity and was able to assign the correct genotype to all the 1,379 genomes that were present in our database.

\section{$\underline{\text { Temporal and geographic distribution of different genotypes }}$}

Upon the establishment of the "Paratype" scheme, we considered the geographical distribution of the different genotypes (Figure 3 ). Genotype 0.1 under primary clade 0 was phylogenetically unique (matches with lineage $\mathrm{H}$ of Zhou et al [5]); there was only one isolate belonging to this genotype/primary clade that was isolated in Hong Kong in 1971. The genome of this isolate was distinct from all other genomes obtained thus far, contained 1288 unique SNPs, and may represent a lineage that is now extinct, or present at very low numbers in areas that have not been sampled. The other two primary clades, clades 1 and 2, emerged between 1700-1800 and contain genomes that have been collected in the last two decades. Clade 1 contains strains largely from lineage F, and fastBAPS predicted two sub-clusters within this clade. One of these clusters was largely found in Bangladesh and has been 
medRxiv preprint doi: https://doi.org/10.1101/2021.11.13.21266165; this version posted November 28, 2021. The copyright holder for this

assigned secondary clade 1.2, then sub-divided into genotypes 1.2.1 and 1.2.2 which appear to have diverged in the 1950s. Both these genotypes are currently present in Bangladesh and other South Asian countries (Figure 2). The other cluster with13 genomes from Bangladesh that were first isolated in 1999 have been assigned to genotype 1.1. The remaining 10 genomes were obtained between 1917 to 1963 and have been assigned genotype 1.0.

Most Salmonella Paratyphi A genomes (1254/1379; 91\%) have been assigned to primary clade 2, which contains genomes belonging to the lineage A-E of the previous scheme. Genomes that belonged to lineages B, D, and $\mathrm{E}$ have now been assigned to genotypes 2.4, 2.2, and 2.0, respectively. Within genotype 2.0, 13 unique and recent isolates from Pakistan were identified and have been assigned as genotype 2.0.1. Genotype 2.1 contains isolates from Nepal that were sampled during the SEAP study, yet the genotype emerged in the 1800 s and is distinct from all other isolates in clade 2. Two clusters in fastBAPS, comprising of strains largely from what was formerly $\mathrm{C}$ lineage are now assigned to genotype 2.3. Genotype 2.3 has been subdivided into genotypes 2.3.1 to 2.3.3, each of which belongs to a distinct geographical location: 2.3.1 is found predominantly in Cambodia and South-East Asia; 2.3.2 and 2.3.3 are found largely in South Asia. An outbreak of paratyphoid fever in China during 2010 - 2011 [7] was caused by isolates of genotype 2.3.3, and these likely originated in South Asia. The former lineages A and B have been assigned genotype 2.4, which is further divided into 2.4.1 to 2.4.4. While genotypes 2.4.1 and 2.4.2 have been observed in different countries in South Asia, genotype 2.4.4 is predominantly found in Bangladesh, and 2.4.3 is largely present in Nepal. 
medRxiv preprint doi: https://doi.org/10.1101/2021.11.13.21266165; this version posted November 28, 2021. The copyright holder for this

240 Different countries in South Asia had unique genotype distributions. Predominant genotypes

241 present in Bangladesh were 2.4.4 (56\%) followed by 1.2.2 (14\%) and 2.3.3 (13\%). In Nepal,

$242 \quad 2.4 .3(47 \%), 2.3 .3(16 \%)$ and 2.4.1 (14\%) were three most common genotypes. Pakistan had

243 genotypes $2.3 .3(25 \%), 2.3(16 \%)$ and $2.4(15 \%)$. In India, genotypes $2.4 .2(22 \%), 2.4(20 \%)$,

$244 \quad 2.4 .1(19 \%), 2.3 .3(17 \%)$, and $2.3(16 \%)$ were commonly identified.

246 Antimicrobial resistance markers in Salmonella Paratyphi A

247 To characterize genomic determinants of antimicrobial resistance in Salmonella Paratyphi A, 248 we screened the 1,379 genomes for the presence of antimicrobial genes and markers using 249 ResFinder [20] (Figure 4a) and plasmids using PlasmidFinder [21] (Figure 4b). Of the 1,379 250 isolates, $1,015(74 \%)$ isolates showed no predicted plasmids and 1356/1379 had no predicted 251 antimicrobial resistance genes. Five genomes with the IncHI1 plasmid were identified, two 252 genomes (both from India) contained resistance genes for trimethoprim and chloramphenicol, 253 and the other three genomes contained genes for trimethoprim, chloramphenicol and 254 ampicillin designated as MDR isolates (one each from India, Pakistan, and Thailand). All five 255 genomes belonged to genotype 2.3 and the strains were isolated between 1999-2004. We also 256 identified a genome belonging to genotype 2.4 .4 containing blaCTX-M-15 and blaTEM-1B 257 on an IncI1-I plasmid; the originating strain was isolated from a patient who contracted the 258 infection in Bangladesh in 2017 [22]. There were 14 isolates from the genotype 2.3.1 that 259 contain blaTEM-116, which can lead to resistance to ampicillin; all 14 were reported from 260 Cambodia[6]. Another isolate from genotype 2.3.3 (from Pakistan, 2015) contained a qnrB19 261 gene on a Col(pHAD28) plasmid, which has been shown to lead to quinolone resistance in other Salmonella species [23]. 
medRxiv preprint doi: https://doi.org/10.1101/2021.11.13.21266165; this version posted November 28, 2021. The copyright holder for this

264 In addition to antimicrobial resistance genes, we also identified chromosomal mutations in

265 the $a \operatorname{cr} B$ gene and the quinolone resistance determining region (QRDR) to identify isolates

266 resistant to azithromycin and ciprofloxacin respectively. Six of 1,379 genomes contained an

267 AcrB R717 mutation, all from Bangladesh and these belonged to genotypes 2.3.3 (1/6) and

268 2.4.4 (5/6) [24,25]. The first azithromycin resistant Salmonella Paratyphi A isolate was

269 identified in 2014, and this resistance has emerged independently at least twice in two

270 different genotypes. On the other hand, a majority $(1177 / 1397 ; 84 \%)$ of genomes had

271 mutations in the QRDR region. The most commonly found single mutation was gyrA-S83F

272 (941/1379), followed by gyrA-S83Y (205/1379). Two isolates contained double mutations in

273 the QRDR region; one of them belonged to genotype 2.0.1 (gyrA-S83F \& D87N, Pakistan,

274 2017) and another belonged to genotype 2.3.3 (gyrA-S83F \& D87G, UK, 2016). Barring

275 genotype $0.1,1.0$ and 2.2, all other genotypes had at least one genome with a QRDR

276 mutation (Figure 4c). The first QRDR mutation was identified in 1997 in India in genotype

2772.4 and their prevalence have increased over time. In 2012 and 2013, there was an outbreak

278 in Cambodia caused by a strain from genotype 2.3.1 that did not have any QRDR mutation

279 leading to a temporary increase in proportion of Salmonella Paratyphi A with no QRDR

280 mutations during these two years (Additional file 1: Figure S3).

Characterization of mutations in the O2-antigen biosynthetic gene cluster

283 The majority of the vaccines being developed for Salmonella Paratyphi A use the O2-antigen

284 that is unique to this serovar conjugated to a carrier protein [26]. Recently, through in-silico

285 metabolic reconstruction, an $18.9 \mathrm{~kb}$ region containing genes involved in O-antigen

286 biosynthesis was identified as important for determining the specific molecular features of the

287 O2-antigen found in Salmonella Paratyphi A [27]. We identified the SNPs in the O2-antigen

288 biosynthesis genes found in the 1,379 genomes to investigate the conservation of this 
medRxiv preprint doi: https://doi.org/10.1101/2021.11.13.21266165; this version posted November 28, 2021. The copyright holder for this

290

291

292

293

294

295

296

297

298

299

300

301

302

303

304

305

306

307

genomic loci. In total, 84 SNPs were found, of which 13 were present in more than 10

genomes. The most common SNP was at genomic location 8,68,444 (G>C ; synonymous

mutation in prt gene encoding paratose synthase), which was found in $17 \%(239 / 1,379)$ of all

isolates. Out of those 13 common SNPs ( $\mathrm{n} \geq 10$ ), seven led to non-synonymous mutations

(Additional file 1: Figure S4) that could potentially change the O2-antigen structure and chemistry.

\section{Discussion}

Salmonella Paratyphi A is the causative agent of paratyphoid fever, a neglected tropical disease with a high burden and mortality in low-and-middle-income countries. Limited information is available regarding its genomic diversity, especially from South Asian countries that collectively are responsible for over $80 \%$ of all paratyphoid cases. As genomic surveillance becomes more prominent, there is a need for a coherent and easy-to-use scheme that can be deployed by public health researchers that do not require extensive compute resources.

We sequenced 817 isolates from Bangladesh, Pakistan and Nepal collected over the last 20 years and compiled a collection of all genomes of Salmonella Paratyphi A publicly available thus far. We describe a genotyping framework for Salmonella Paratyphi A using 1,379 isolates obtained from 1917 through 2019. Rather than being guided by a single approach, we combined ML-based phylogenetics with BAPS and Bayesian analysis via BEAST to design a genotyping scheme for Salmonella Paratyphi A. The scheme divided the Salmonella

Paratyphi A population into 18 different genotypes, and each can be identified by the presence of an allele that is located on the coding sequence of a conserved gene, involved in 
medRxiv preprint doi: https://doi.org/10.1101/2021.11.13.21266165; this version posted November 28, 2021. The copyright holder for this

housekeeping functions. We only found 8,346 SNPs from all 1,379 isolates, with minimal

314 recombination, and thus, this genotyping scheme based on SNP alleles can support robust

315 genotyping and accommodate future evolution of Salmonella Paratyphi A. And to assist with

316 that, we have developed Paratype, an open-source Python script for genotyping of Salmonella

317 Paratyphi A genomes. Paratype can detect the genotype of Salmonella Paratyphi A genomes

318 directly from raw fastq read data. It can also detect mutations in the acrB efflux pump

319 (determinant of macrolide resistance) and in the QRDR region (determinant of ciprofloxacin 320 non-susceptibility).

In this genotyping scheme, we propose three primary clades 0,1 , and 2 , which diverged

before the 1800s (Figure 2). While only a single isolate of primary clade 0 was obtained in

decades. Clade 2 is the most abundant and has been subdivided into four secondary clades:

$2.1-2.4$, which probably emerged in the 1800 s or the early 1900 s. Clade 2.3 could be

subdivided into 2.3.1 - 2.3.3, each with distinct geographic distribution. Clade 2.4 was also

sub-divided into genotypes 2.4 .1 - 2.4.4. Genotype 2.4 .4 was the most abundant and was

(blaCTX-M-15) [22]. 
medRxiv preprint doi: https://doi.org/10.1101/2021.11.13.21266165; this version posted November 28, 2021. The copyright holder for this

preprint (which was not certified by peer review) is the author/funder, who has granted medRxiv a license to display the preprint in perpetuity.

All rights reserved. No reuse allowed without permission.

337 Although a few isolates did acquire the IncHI1 plasmid in the late 1990s to early 2000s

338 (Figure 4a), no massive spread across the globe was noted; this unlike Salmonella Typhi

339 lineage H58 (genotype 4.3.1) carrying the IncHI1 plasmid spread and became the dominant

340 lineage in the last 30 years[28]. This is also true for chromosomal mutations such as QRDR

341 and AcrB mutations, which are overall less prevalent in Salmonella Paratyphi A than in

342 Salmonella Typhi [28,29]. Considering the genetic similarities between Salmonella Typhi

343 and Paratyphi A, and the fact that they occupy the same environmental niche, the differences

344 in the presence of AMR genes between these typhoidal Salmonella serovars warrants further

345 investigation.

347 The specific O-antigen in the Salmonella Paratyphi A is thought to be conserved (assigned to 348 serogroup O2) and several vaccine candidates are currently under development, utilizing the

$349 \mathrm{O} 2$ antigen conjugated to a carrier protein as the main vaccine antigen. We compared the 18.9

$350 \mathrm{kbp}$ region responsible for the synthesis of the $\mathrm{O} 2$ antigen in this serovar [27] and found 83

351 SNPs in this region, of which 7 non-synonymous mutations were present in $>10$ isolates.

352 While it is not clear if these mutations affect the $\mathrm{O} 2$-antigen chemistry, the low mutation rate

353 and no observed recombination events in the cluster suggests that the $\mathrm{O} 2$ antigen vaccine will

354 have a broadly protective response against all the Salmonella Paratyphi A genotypes sampled

355 thus far. However, any variations in this region should be carefully monitored through

356 genomic surveillance.

358 The conclusions that we can draw from this analysis are subject to certain limitations. First,

359 the available genomes are an incomplete sample; Salmonella Paratyphi A is a neglected

360 pathogen, and hence the available genomes and might not have broad representativeness 
medRxiv preprint doi: https://doi.org/10.1101/2021.11.13.21266165; this version posted November 28, 2021. The copyright holder for this preprint (which was not certified by peer review) is the author/funder, who has granted medRxiv a license to display the preprint in perpetuity. All rights reserved. No reuse allowed without permission.

across geographies or time. Specifically, a small proportion of genomes were available from countries in sub-Saharan Africa and India. Second, while the tool has high sensitivity and specificity on our dataset, as more genomes become available over time and novel mechanism of AMR emerge, this tool will require updates from the bigger scientific community. Like all genotyping tools, Paratype is a living tool that will require updates. Our diverse group of authors plans to continually monitor the library of publicly available genomes, accept update requests via GitHub, and incorporate any required updates in the Paratype scheme accordingly.

\section{Conclusions}

This study reports the first large-scale global analysis of Salmonella Paratyphi A genomes and proposes the first genotyping tool for this pathogen. Paratype, which has already been released (https://github.com/CHRF-Genomics/Paratype) as an open-access, easy-to-use, command-line tool, is being tested and adopted by researchers for large scale genomic analysis (https://doi.org/10.5281/zenodo.5520408). This tool will assist future genomic surveillance studies and will help inform prevention and treatment strategies for this neglected pathogen.

\section{$\underline{\text { Methods }}$}

\section{$\underline{\text { Study site and isolate selection }}$}

Child Health Research Foundation in Bangladesh has been preserving invasive Salmonella isolates since 1999 and maintains a biobank of >9000 typhoidal Salmonella isolates, largely from children ( $<18 \square$ years of age) that were isolated from the blood of the patients in two different settings: in-patient (hospitalized), and out-patient (community) facility [30]. Clinical 
medRxiv preprint doi: https://doi.org/10.1101/2021.11.13.21266165; this version posted November 28, 2021. The copyright holder for this

and epidemiological data were collected for all hospitalized patients. From this biobank, among 640 Salmonella Paratyphi A isolates collected till December 2016, 348 were randomly selected for whole-genome sequencing (WGS) (Additional file 1: Table S1). A set of 469 Salmonella Paratyphi A isolates were also added to this collection, isolated under the Surveillance for Enteric Fever in Asia (SEAP) project from three different typhoid-endemic countries, Bangladesh $(n=180)$, Nepal $(n=156)$, and Pakistan $(n=133)$. The SEAP-

Bangladesh isolates $(n=180)$ were selected using randomization to represent 483 isolates collected between 2016 and 2018. In contrast, SEAP-Nepal isolates included all pre-SEAP isolates (2014 - 2016) and randomly selected SEAP isolates (2017 - 2019). The SEAPPakistan isolates were selected prioritizing the availability of geographic information and susceptibility profile during 2016 - 2018 .

To add to all the isolates sequenced in this study, we also collected raw fastq data of 560 Salmonella Paratyphi A isolates from 37 different countries and 10 published articles (Additional file 1: Table S2). Complete chromosomal sequences of Salmonella Paratyphi A ATCC 9150 (NC_006511) and AKU_12601 (NC_011147) were also included [31,32]. For travel-related paratyphoid cases, the country of "traveling from" was considered as the country of origin. If no travel data is available, the country of "reported from" was considered as the country. Overall, for globally distributed 562 Salmonella Paratyphi A, year and country data were available for 507 and 536 respectively (Additional file 1: Table S2). In total, we obtained a global collection of 1,379 Salmonella Paratyphi A covering a timeline of 1917 2019 and 37 countries [see Additional file 2 for more details].

Whole-genome sequencing 
medRxiv preprint doi: https://doi.org/10.1101/2021.11.13.21266165; this version posted November 28, 2021. The copyright holder for this

Salmonella Paratyphi A isolates from 1999-2016 (before the start of the SEAP project) from

410 Bangladesh $(\mathrm{n}=348)$ were subcultured on MacConkey agar media and kept overnight at $37^{\circ} \mathrm{C}$.

411 In case of any visible contamination, a single colony was picked and subcultured again.

412 Later, all colonies were swapped and resuspended into $1 \mathrm{ml}$ of water. From this suspension,

$413400 \mu \mathrm{L}$ was used for DNA extraction using the QIAamp DNA Mini Kit (Qiagen, Hilden,

414 Germany) and sent to Novogene (NovogeneAIT, Singapore) for WGS on Novaseq 6000

415 platform (PE150). All SEAP isolates were extracted using the same protocol and were

416 sequenced on Illumina HiSeq 4000 platform (PE150) at the Welcome Sanger Institute,

417 Cambridge, UK.

$\underline{\text { Systematic literature review of existing Salmonella Paratyphi A genomes }}$

To contextualize the genomes sequenced in this study, we conducted a systematic search to

421 compile all publicly available Salmonella Paratyphi A genomes (for which raw reads and

422 metadata were available) to build a database of 560 additional isolates from 10 studies

423 (Additional file 1: Table S2). First, the search terms "(Salmonella Paratyphi A) AND

424 (Molecular Epidemiology)" "Salmonella Paratyphi A genome" and "(Salmonella Paratyphi

425 A) AND (Genomic Epidemiology)" were used in PubMed advanced search builder. Next, the

426 hits were filtered by selecting dates between 1900 and 2019 and the total number of

427 publications remaining were 231 . After screening the abstracts and titles manually and

428 eliminating duplicated, only 7 studies were found to have any kind of genome/metadata

429 available for further analysis. In addition, three studies $[8,9,22]$ that meets our criteria

430 (published and both metadata and raw reads available) but missed/not published during the

431 initial PubMed search were incorporated from European Nucleotide Archive (ENA) database,

432 taking the final number of incorporated publications to 10. 
medRxiv preprint doi: https://doi.org/10.1101/2021.11.13.21266165; this version posted November 28, 2021. The copyright holder for this

434 Quality check, genome assembly, annotation, and pan-genome analysis

435 Raw fastq reads of all Salmonella Paratyphi A were quality-checked using FastQC and

436 trimmed using Trimmomatic if necessary[33]. All 1,377 sets of raw fastq reads were

437 assembled using Unicycler v0.4.8 (default with --min_fasta_length 200)[34]. The assembled

438 contigs $(n=1,377)$ and downloaded complete chromosomes $(n=2)$ were annotated using

439 Prokka (--gcode 11 --mincontiglen 200) [35]. The annotated GFF files of all 1,379 isolates

440 were used to build a pan- and core-genome of Salmonella Paratyphi A using Roary v3.3 (

441 options: $-t 11-e--m a f f t-n)[36]$. The gene_presence_absence matrix output was used to

442 perform the Heap's law analysis to understand the open/closedness of the pan-genome (heaps

443 function of micropan library on R; 1000 permutations).

\section{SNP-based phylogenetic analyses}

446 For the complete "global+SEAP" raw data collection, fastq reads of 1,377 Salmonella

447 Paratyphi A and fasta of two RefSeq chromosomes (NC_006511 and NC_011147) were

448 mapped against the Salmonella Paratyphi A AKU_12601 (FM200053.1) using Bowtie2

449 v2.3.5.1 [37]. Candidate SNPs were identified using SAMtools (v1.10) and BCFtools

450 (v1.10.2) [38]. Only the homozygous, unambiguous SNPs with a Phred-quality score of $>20$

451 were selected using a customized Python script. SNPs were discarded if they had strand bias

$452 \mathrm{p}<0.001$, mapping bias $\mathrm{p}<0.001$ or tail bias $\mathrm{p}<0.001$ (using vcfutils.pl script, from

453 SAMtools). SNPs located in phage or repeat regions (118.9 kb for Salmonella Paratyphi A

454 AKU_12601 as described in Sajib et al. [25]) were also excluded using a customized python

455 script. Gubbins v2.3.4 was used to detect the recombinant regions [39] and SNPs in those

456 regions were excluded as well using the same python script, resulting in a set of 8,346 
medRxiv preprint doi: https://doi.org/10.1101/2021.11.13.21266165; this version posted November 28, 2021. The copyright holder for this

chromosomal SNPs positions for the "global+SEAP" collection $(n=1,379)$. All SNP alleles

were extracted (fasta) using a customized python script and merged to produce SNP

alignment.

Maximum likelihood trees (MLT) were built from the chromosomal SNP alignments using

RAxML v8.2.12 (with the Generalized Time-Reversible model and a Gamma distribution to

model site-specific rate variation; GTRGAMMA in RAxML) [15]. Support for the MLT was

calculated using 100 bootstrap pseudo-analyses of the alignment. The MLT was outgroup-

rooted by including the pseudo-alleles from Salmonella Typhi CT18 (NC_003198.1) in the

alignment. Tree visualization was done using iTol v5.5 [40], including the previous Paratyphi

467 A lineages proposed by Zhou et al [5].

In addition to SNP-based MLT, we investigated the population structure of the global

471 Salmonella Paratyphi A collection using a Bayesian approach, implemented with the SNP

472 alignment using fastBaps ${ }^{40}$. To maintain compatibility with the phylogeny, some minor

473 modifications were made to the clustering pattern proposed by the least conservative

474 Dirichlet prior hyperparameters on fastbaps, optimise.baps. This eventually resulted in a total

475 of 16 different clusters. A customized python script was used to randomly select two

476 isolates/year/cluster to represent this global collection of Salmonella Paratyphi A, leading to

477 two independent sample sets of 315 isolates each. The alignment of SNP-alleles for this

478 representative sample set was used to understand the evolutionary diverging pattern of

479 different Salmonella Paratyphi A clusters over time using BEAST v1.10.4 [19]. The

$480 \mathrm{GTR}+\Gamma(4)$ substitution model was selected for this analysis with the exponential unrelated 
medRxiv preprint doi: https://doi.org/10.1101/2021.11.13.21266165; this version posted November 28, 2021. The copyright holder for this

relaxed clock as clock type and Bayesian skyline coalescent model as tree prior. The analysis considered the year of isolation as tip dates and continued for 500 million steps with sampling every 50,000 iterations. The BEAST analysis was run twice each on the two independently generated sets of isolates. The resulting log files and model parameters were analyzed on Tracer v1.7.1. TreeAnnotator v1.10 was used to generate the maximum-cladecredibility (MCC) tree [41]. The tree was visualized on FigTree v1.4.4 with a time scale. For the model with the highest posterior values (joint effective sample size (ESS) of 544) used for further analysis, time to last common ancestor (MRCA) was calculated to be 1407 AD (95\% highest posterior density (HPD) interval [721.0, 1637.3]). Based on the diverging patterns suggested by the MCC tree, we assigned the clusters (defined as described above) into primary clades, secondary clades, and subclades on the MLT. However, a few visible clusters on the MLT could not be assigned to specific subclades due to a lack of clustering information from fastBaps, likely due to the low number of SNPs unique to these clusters.

\section{SNP-based genotyping scheme and paratype}

We further divided the 16 clusters obtained from fastBAPS into 18 genotypes and identified a set of 18 SNP alleles, located in a coding sequence for conserved genes to define each assigned secondary clade and sub-clades. Each SNP allele was unique to only one subclade or, to one secondary clade and its corresponding subclades (if any). Therefore, we assigned the term "genotype" to each of the 18 secondary clades or subclades. Sorted read alignment (BAM) files generated during the SNP analysis were used to assign the genotypes for each isolate using a customized Python script, named Paratype (available at https://github.com/CHRF-Genomics/Paratype). Briefly, under BAM mode (--mode bam), Paratype uses samtools index (if bam file is not indexed), samtools mpileup, and bcftools call to extract the consensus base calls at those 18 SNP loci from the BAM file. The resulting 
medRxiv preprint doi: https://doi.org/10.1101/2021.11.13.21266165; this version posted November 28, 2021. The copyright holder for this

variant call format (VCF) file is then processed to identify the presence of the defining SNP alleles and follow cladistic logic to assign the genotype of the isolate, as well as the primary clade, secondary clades, and subclade information. Paratype only considers high-quality SNP alleles (Phred score $>20$ and 75\% read_ratio for the allele) to assign genotypes. Read_ratio is calculated by the number of high-quality alternative-allele reads on both strands, divided by the total number of high-quality reads. In addition, Paratype also has fastq mode (--mode fastq) where a user can provide a set of paired-end raw fastq data file (can be gzipped) and Paratype performs reference mapping (against the Salmonella Paratyphi AKU_12601 genome) using Bowtie and SAMtools and follows the same steps described above to detect the genotype of the isolates. Although the bam mode is the default for the tool, the fastq mode is more accurate and should be user-friendly to non-coding specializing researchers; however, it is more time-consuming. Paratype also runs on vcf mode (--mode vcf) which is faster, but also the least accurate if the provided SNPs are not highly trusted.

\section{Plasmid, resistance gene, and mutation analysis}

All assembled contigs were screened with PlasmidFinder v2.1 [21] and ResFinder v3.2 [20] to detect plasmid amplicons and acquired AMR genes respectively. Both results were parsed using customized python scripts. To detect mutations in $\operatorname{gyr} A$ and $\operatorname{acr} B$ genes, we used the same Paratype script. It uses the same files used for genotyping and produces gene- and position-specific non-silent and silent mutation results.

We also explored the genomic region where the genes related to $\mathrm{O} 2$-antigen biosynthesis are located (860,008 - 878,865 of AKU_12601 genome). We detected all SNPs in that region with the number of isolates having those and their corresponding amino-acid changes using 
medRxiv preprint doi: https://doi.org/10.1101/2021.11.13.21266165; this version posted November 28, 2021. The copyright holder for this preprint (which was not certified by peer review) is the author/funder, who has granted medRxiv a license to display the preprint in perpetuity. All rights reserved. No reuse allowed without permission.

530 the Paratype. Two additional python scripts were used to count position-specific SNPs and 531 mutations for the $18.9 \mathrm{kbp}$ region.

532

533 Data visualization and statistical analysis

$534 \mathrm{R}$ (v4.0.4) base function and several packages including dplyr, ggplot2, micropan and 535 scatterpie were used for data visualization and statistical analysis.

537 Declarations

$538 \quad$ Ethics approval and consent to participate

539 Ethical approval for the parent studies were obtained from the Bangladesh Institute of Child

540 Health Ethical Review Committee, Nepal Health Research Council, Aga Khan University

541 Hospital Ethics Committee and Pakistan National Ethics Committee, Stanford University

542 Institutional Review Board, and U.S. Centers for Disease Control and Prevention. Informed

543 written consent and clinical information were taken from adult participants and legal

544 guardians of child participants.

545

546 Consent for publication

547 Not applicable (No data from individual person was used for analysis).

$549 \quad$ Availability of data and materials

550 The genome dataset supporting the conclusions of this article are available in the European 551 Nucleotide Archive (ENA) under study accession ERP132884. The genotyping tool for 
medRxiv preprint doi: https://doi.org/10.1101/2021.11.13.21266165; this version posted November 28, 2021. The copyright holder for this preprint (which was not certified by peer review) is the author/funder, who has granted medRxiv a license to display the preprint in perpetuity.

All rights reserved. No reuse allowed without permission.

552 Salmonella Paratyphi A, Paratype is available at https://github.com/CHRF-

553 Genomics/Paratype (https://doi.org/10.5281/zenodo.5520408). Customized Python scripts

554 and color scheme used in the manuscript are available at https://github.com/CHRF-

555 Genomics/CHRF Paratyphi scripts. The metadata supporting the conclusions of this article

556 is included in Additional file 2.

557

$558 \quad$ Competing interests

559 The authors declare no competing interests.

560

$561 \quad$ Funding

562 This study was supported by the Bill and Melinda Gates Foundation (grant numbers INV-

563023821 and INV-008335). The funding body did not have any role in the design of the study, 564 analysis, and interpretation of data or, in writing the manuscript.

566 Authors' contributions

567 AMT, YH, MSIS, SKS and SS were involved in conceptualization and design of the study.

568 MSIS performed the DNA extraction for sequencing in Bangladesh and the literature review

569 for the global database construction. AMT, YH and MSIS performed bioinformatic analysis

570 under supervision of SS and SKS. JRA provided continuous guidance during bioinformatic

571 analysis. AMT and YH designed the genotyping scheme and AMT wrote the Paratype script.

572 YH and MSIS conducted the statistical analyses and visualization. KES, JI, ZAD, SB and

573 JRA reviewed the results. ZAD and SB reviewed genotyping scheme and the Paratype tool.

574 AMT, YH, MSIS and SS wrote the first draft of the manuscript. KES, JI, FNQ, SPL, GD, 
medRxiv preprint doi: https://doi.org/10.1101/2021.11.13.21266165; this version posted November 28, 2021. The copyright holder for this

575 ZAD, SB, DOG, JRA and SKS reviewed the manuscript. All authors reviewed and approved 576 the final manuscript.

$578 \quad \underline{\text { Acknowledgements }}$

579 We are thankful to Mr. Hafizur Rahman, Mr. Dipu Chandra Das and Ms. Nusrat Alam of the

580 Child Health Research Foundation for their help with the wet-lab procedures. We are also

581 thankful to the entire SEAP team for their unwavering support and coordination between the 582 teams.

\section{$584 \quad \underline{\text { References }}$}

585 1. Stanaway JD, Reiner RC, Blacker BF, Goldberg EM, Khalil IA, Troeger CE, et al. The 586 global burden of typhoid and paratyphoid fevers: a systematic analysis for the Global Burden 587 of Disease Study 2017. The Lancet Infectious Diseases [Internet]. [cited 2019 Feb 28];0.

588 Available from: https://www.thelancet.com/journals/laninf/article/PIIS1473-3099(18)30685-

$5896 /$ abstract

590 2. Crump JA, Mintz ED. Global trends in typhoid and paratyphoid fever. Clin Infect Dis.

$591 \quad 2010 ; 50: 241-6$.

592 3. Lu X, Li Z, Yan M, Pang B, Xu J, Kan B. Regional Transmission of Salmonella Paratyphi

593 A, China, 1998-2012. Emerg Infect Dis. 2017;23:833-6.

594 4. Furuse Y. Analysis of research intensity on infectious disease by disease burden reveals

595 which infectious diseases are neglected by researchers. PNAS. National Academy of

596 Sciences; 2019;116:478-83. 
medRxiv preprint doi: https://doi.org/10.1101/2021.11.13.21266165; this version posted November 28, 2021. The copyright holder for this preprint (which was not certified by peer review) is the author/funder, who has granted medRxiv a license to display the preprint in perpetuity.

All rights reserved. No reuse allowed without permission.

597

598

599

600

601

602

603

604

605

606

607

608

609

610

611

612

613

614

615

616

617

618

5. Zhou Z, McCann A, Weill F-X, Blin C, Nair S, Wain J, et al. Transient Darwinian selection in Salmonella enterica serovar Paratyphi A during 450 years of global spread of enteric fever. Proc Natl Acad Sci U S A. 2014;111:12199-204.

6. Kuijpers LMF, Le Hello S, Fawal N, Fabre L, Tourdjman M, Dufour M, et al. Genomic analysis of Salmonella enterica serotype Paratyphi A during an outbreak in Cambodia, 20132015. Microb Genom [Internet]. 2016 [cited 2019 Aug 25];2. Available from: https://www.ncbi.nlm.nih.gov/pmc/articles/PMC5320704/

7. Yan M, Yang B, Wang Z, Wang S, Zhang X, Zhou Y, et al. A Large-Scale CommunityBased Outbreak of Paratyphoid Fever Caused by Hospital-Derived Transmission in Southern China. PLOS Neglected Tropical Diseases. Public Library of Science; 2015;9:e0003859.

8. Ashton PM, Nair S, Peters TM, Bale JA, Powell DG, Painset A, et al. Identification of Salmonella for public health surveillance using whole genome sequencing. PeerJ. PeerJ Inc.; 2016;4:e1752.

9. Britto CD, Dyson ZA, Duchene S, Carter MJ, Gurung M, Kelly DF, et al. Laboratory and molecular surveillance of paediatric typhoidal Salmonella in Nepal: Antimicrobial resistance and implications for vaccine policy. PLOS Neglected Tropical Diseases. 2018;12:e0006408.

10. Saha S, Islam M, Uddin MJ, Saha S, Das RC, Baqui AH, et al. Integration of enteric fever surveillance into the WHO-coordinated Invasive Bacterial-Vaccine Preventable Diseases (IBVPD) platform: A low cost approach to track an increasingly important disease. PLOS Neglected Tropical Diseases. 2017;11:e0005999.

11. Saha S, Islam M, Saha S, Uddin MJ, Rahman H, Das RC, et al. Designing Comprehensive Public Health Surveillance for Enteric Fever in Endemic Countries: Importance of Including Different Healthcare Facilities. J Infect Dis. 2018;218:S227-31. 
medRxiv preprint doi: https://doi.org/10.1101/2021.11.13.21266165; this version posted November 28, 2021. The copyright holder for this preprint (which was not certified by peer review) is the author/funder, who has granted medRxiv a license to display the preprint in perpetuity. All rights reserved. No reuse allowed without permission.

620 12. Saha S, Islam MS, Sajib MSI, Saha S, Uddin MJ, Hooda Y, et al. Epidemiology of

621 Typhoid and Paratyphoid: Implications for Vaccine Policy. Clin Infect Dis. 2019;68:S117-

622

23.

13. Barkume C, Date K, Saha SK, Qamar FN, Sur D, Andrews JR, et al. Phase I of the

624 Surveillance for Enteric Fever in Asia Project (SEAP): An Overview and Lessons Learned. J

625 Infect Dis. 2018;218:S188-94.

626 14. Day MR, Doumith M, Do Nascimento V, Nair S, Ashton PM, Jenkins C, et al.

627 Comparison of phenotypic and WGS-derived antimicrobial resistance profiles of Salmonella

628 enterica serovars Typhi and Paratyphi. Journal of Antimicrobial Chemotherapy.

$629 \quad 2018 ; 73: 365-72$.

630 15. Stamatakis A. RAxML version 8: a tool for phylogenetic analysis and post-analysis of

631 large phylogenies. Bioinformatics. 2014;30:1312-3.

16. Britto CD, Dyson ZA, Mathias S, Bosco A, Dougan G, Jose S, et al. Persistent circulation

633 of a fluoroquinolone-resistant Salmonella enterica Typhi clone in the Indian subcontinent.

634 Journal of Antimicrobial Chemotherapy. 2020;75:337-41.

635 17. Sherchan JB, Morita M, Matono T, Izumiya H, Ohnishi M, Sherchand JB, et al.

636 Molecular and Clinical Epidemiology of Salmonella Paratyphi A Isolated from Patients with

637 Bacteremia in Nepal. The American Journal of Tropical Medicine and Hygiene. The

638 American Society of Tropical Medicine and Hygiene; 2017;97:1706-9.

639 18. Tonkin-Hill G, Lees JA, Bentley SD, Frost SDW, Corander J. Fast hierarchical Bayesian

640 analysis of population structure. Nucleic Acids Res. 2019;47:5539-49.

641 19. Drummond AJ, Rambaut A. BEAST: Bayesian evolutionary analysis by sampling trees.

642 BMC Evolutionary Biology. 2007;7:214. 
medRxiv preprint doi: https://doi.org/10.1101/2021.11.13.21266165; this version posted November 28, 2021. The copyright holder for this

643 20. Bortolaia V, Kaas RS, Ruppe E, Roberts MC, Schwarz S, Cattoir V, et al. ResFinder 4.0

644 for predictions of phenotypes from genotypes. Journal of Antimicrobial Chemotherapy.

$645 \quad 2020 ; 75: 3491-500$.

646 21. Carattoli A, Hasman H. PlasmidFinder and In Silico pMLST: Identification and Typing

647 of Plasmid Replicons in Whole-Genome Sequencing (WGS). Methods Mol Biol.

$648 \quad 2020 ; 2075: 285-94$.

22. Nair S, Day M, Godbole G, Saluja T, Langridge GC, Dallman TJ, et al. Genomic

650 surveillance detects Salmonella enterica serovar Paratyphi A harbouring blaCTX-M-15 from

651 a traveller returning from Bangladesh. PLOS ONE. Public Library of Science;

$652 \quad 2020 ; 15: \mathrm{e} 0228250$.

653 23. Jibril AH, Okeke IN, Dalsgaard A, Menéndez VG, Olsen JE. Genomic Analysis of

654 Antimicrobial Resistance and Resistance Plasmids in Salmonella Serovars from Poultry in

655 Nigeria. Antibiotics. Multidisciplinary Digital Publishing Institute; 2021;10:99.

656 24. Hooda Y, Sajib MSI, Rahman H, Luby SP, Bondy-Denomy J, Santosham M, et al.

657 Molecular mechanism of azithromycin resistance among typhoidal Salmonella stains in

658 Bangladesh identified through passive pediatric surveillance. PLOS Neglected Tropical

659 Diseases. 2019;13:e0007868.

660

661

662

663

664

665

666
25. Sajib MSI, Tanmoy AM, Hooda Y, Rahman H, Andrews JR, Garrett DO, et al. Tracking the Emergence of Azithromycin Resistance in Multiple Genotypes of Typhoidal Salmonella. mBio [Internet]. American Society for Microbiology; 2021 [cited 2021 Feb 16];12. Available from: https://mbio.asm.org/content/12/1/e03481-20

26. Sahastrabuddhe S, Carbis R, Wierzba TF, Ochiai RL. Increasing rates of Salmonella Paratyphi A and the current status of its vaccine development. Expert Review of Vaccines. Taylor \& Francis; 2013;12:1021-31. 
medRxiv preprint doi: https://doi.org/10.1101/2021.11.13.21266165; this version posted November 28, 2021. The copyright holder for this preprint (which was not certified by peer review) is the author/funder, who has granted medRxiv a license to display the preprint in perpetuity. All rights reserved. No reuse allowed without permission.

27. Seif Y, Monk JM, Machado H, Kavvas E, Palsson BO. Systems Biology and Pangenome of Salmonella O-Antigens. mBio [Internet]. American Society for Microbiology; 2019 [cited 2020 Aug 11];10. Available from: https://mbio.asm.org/content/10/4/e01247-19

28. Wong VK, Baker S, Pickard DJ, Parkhill J, Page AJ, Feasey NA, et al. Phylogeographical analysis of the dominant multidrug-resistant H58 clade of Salmonella Typhi identifies interand intracontinental transmission events. Nat Genet. 2015;47:632-9.

29. Wong VK, Baker S, Connor TR, Pickard D, Page AJ, Dave J, et al. An extended genotyping framework for Salmonella enterica serovar Typhi, the cause of human typhoid. Nature Communications. 2016;7:12827.

30. Saha SK, Baqui AH, Hanif M, Darmstadt GL, Ruhulamin M, Nagatake T, et al. Typhoid fever in Bangladesh: implications for vaccination policy. The Pediatric Infectious Disease Journal. 2001;20:521-4.

31. McClelland M, Sanderson KE, Clifton SW, Latreille P, Porwollik S, Sabo A, et al. Comparison of genome degradation in Paratyphi A and Typhi, human-restricted serovars of Salmonella enterica that cause typhoid. Nature Genetics. Nature Publishing Group; 2004;36:1268-74.

32. Holt KE, Thomson NR, Wain J, Langridge GC, Hasan R, Bhutta ZA, et al. Pseudogene accumulation in the evolutionary histories of Salmonella enterica serovars Paratyphi A and Typhi. BMC Genomics. 2009;10:36.

33. Bolger AM, Lohse M, Usadel B. Trimmomatic: a flexible trimmer for Illumina sequence data. Bioinformatics. 2014;30:2114-20.

34. Wick RR, Judd LM, Gorrie CL, Holt KE. Unicycler: Resolving bacterial genome assemblies from short and long sequencing reads. PLOS Computational Biology. Public Library of Science; 2017;13:e1005595. 
medRxiv preprint doi: https://doi.org/10.1101/2021.11.13.21266165; this version posted November 28, 2021. The copyright holder for this preprint (which was not certified by peer review) is the author/funder, who has granted medRxiv a license to display the preprint in perpetuity. All rights reserved. No reuse allowed without permission.

691 35. Seemann T. Prokka: rapid prokaryotic genome annotation. Bioinformatics.

$692 \quad 2014 ; 30: 2068-9$.

693 36. Page AJ, Cummins CA, Hunt M, Wong VK, Reuter S, Holden MTG, et al. Roary: rapid 694 large-scale prokaryote pan genome analysis. Bioinformatics. 2015;31:3691-3.

695 37. Langmead B, Salzberg SL. Fast gapped-read alignment with Bowtie 2. Nature Methods.

696 Nature Publishing Group; 2012;9:357-9.

697 38. Li H, Handsaker B, Wysoker A, Fennell T, Ruan J, Homer N, et al. The Sequence

698 Alignment/Map format and SAMtools. Bioinformatics. 2009;25:2078-9.

699 39. Croucher NJ, Page AJ, Connor TR, Delaney AJ, Keane JA, Bentley SD, et al. Rapid

700 phylogenetic analysis of large samples of recombinant bacterial whole genome sequences

701 using Gubbins. Nucleic Acids Research. 2015;43:e15-e15.

702 40. Letunic I, Bork P. Interactive Tree Of Life (iTOL) v4: recent updates and new

703 developments. Nucleic Acids Research. 2019;47:W256-9.

704 41. Suchard MA, Lemey P, Baele G, Ayres DL, Drummond AJ, Rambaut A. Bayesian

705 phylogenetic and phylodynamic data integration using BEAST 1.10. Virus Evolution

706 [Internet]. 2018 [cited 2021 Mar 28];4. Available from: https://doi.org/10.1093/ve/vey016 
medRxiv preprint doi: https://doi.org/10.1101/2021.11.13.21266165; this version posted November 28, 2021. The copyright holder for this

preprint (which was not certified by peer review) is the author/funder, who has granted medRxiv a license to display the preprint in perpetuity.

All rights reserved. No reuse allowed without permission.

\section{$708 \quad$ Figure legends}

709 Figure 1: Genotyping scheme for Salmonella Paratyphi A. The scheme is composed of

710 three primary, nine secondary and 18 genotypes on a phylogenetic tree of 1,379 isolates. The

7119 secondary clades as highlighted by the coloring of the inner ring. 18 genotypes identified

712 and are shown in the colored middle ring of the figure. The previously proposed lineage

713 system is shown in the outer ring.

Figure 2: Maximum clade credibility tree of 315 representative Salmonella Paratyphi A

isolates. The tree shows the last common ancestor of all Salmonella Paratyphi A existed at

least 600 years ago (tMRCA - 1407 AD). The different genotypes are temporally resolved.

Countries with greater than or equal to 5 isolates are also included.

Figure 3: Geographical distribution of Salmonella Paratyphi A genotypes. The country

of isolation for 1378 sequenced Salmonella Paratyphi A isolates is shown. The distribution of genotypes per country is shown as scattered pie charts. The size of the each pie chart represents the number of sequences available. A difference in circulating genotypes is observed indicating local populations differ in several endemic countries. Further details are provided in Additional file 2.

Figure 4: Presence of antimicrobial resistance genes, plasmids, and chromosomal 
medRxiv preprint doi: https://doi.org/10.1101/2021.11.13.21266165; this version posted November 28, 2021. The copyright holder for this preprint (which was not certified by peer review) is the author/funder, who has granted medRxiv a license to display the preprint in perpetuity. All rights reserved. No reuse allowed without permission. 
medRxiv preprint doi: https://doi.org/10.1101/2021.11.13.21266165; this version posted November 28, 2021. The copyright holder for this preprint (which was not certified by peer review) is the author/funder, who has granted medRxiv a license to display the preprint in perpetuity. All rights reserved. No reuse allowed without permission.

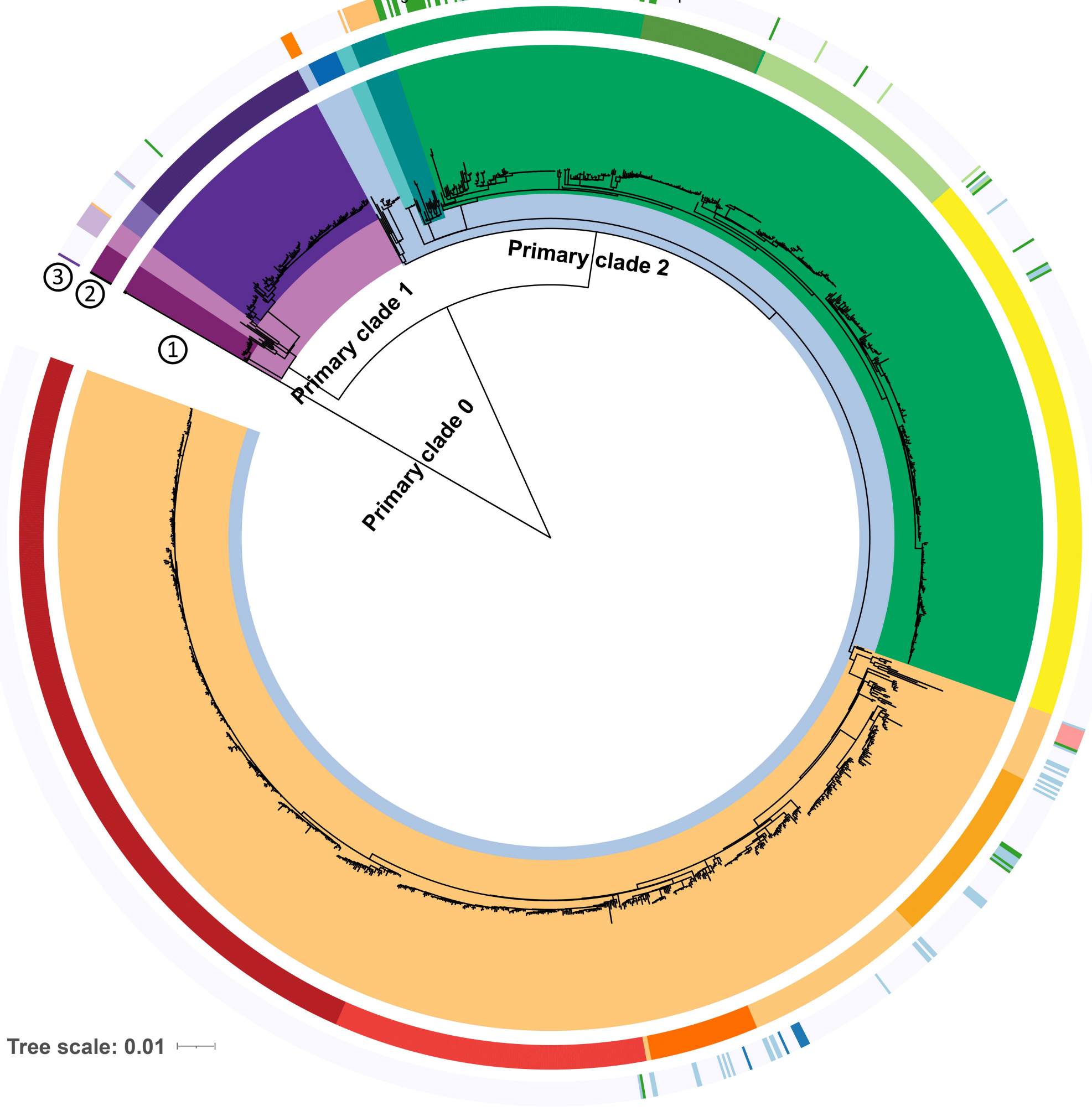

(1) Secondary Clades

$0.1 \square 2.1$
$1.0 \square 2.2$
$1.1 \square 2.3$
$1.2 \square 2.4$
2.0

(2) Genotypes

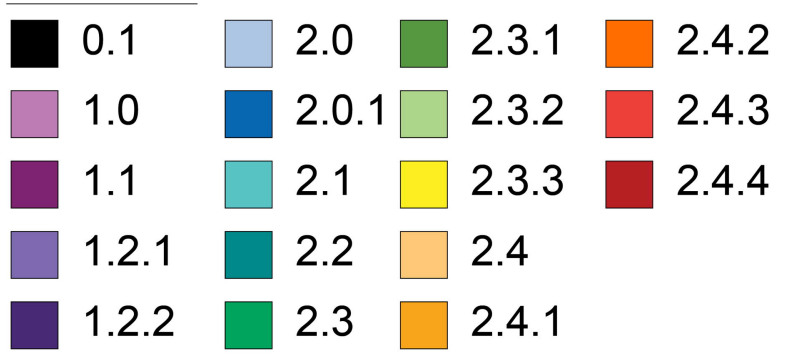

(3) Lineages

$\begin{array}{ll}\square \text { A } & \square \text { C5 } \square \text { NA } \\ \text { A1 } & \square \text { D } \\ \text { B } & \text { E } \\ \text { C } & \text { F } \\ \text { C4 } & \text { G }\end{array}$




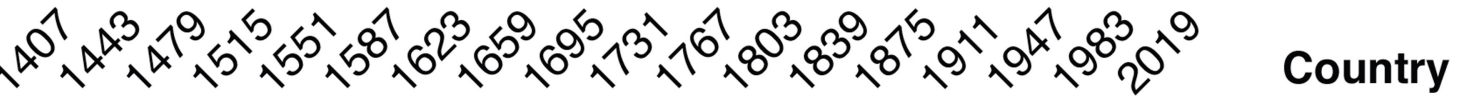

\section{1}

medRxiv preprint doi: https://doi.org/10.1101/2021.11/1B.A1266165; this versid/ posted November 28, 2021. The copyright holder for this preprint (which was not certified by pefreview) is the authorffunder, who has granted medRxiv a liconse to display the preprint in perpetuity. 1.0.ll rights reserved. No reuse-allowed without permission.

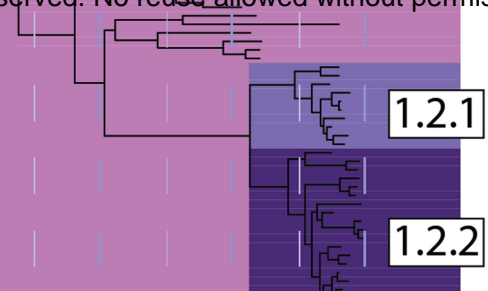

\section{0}
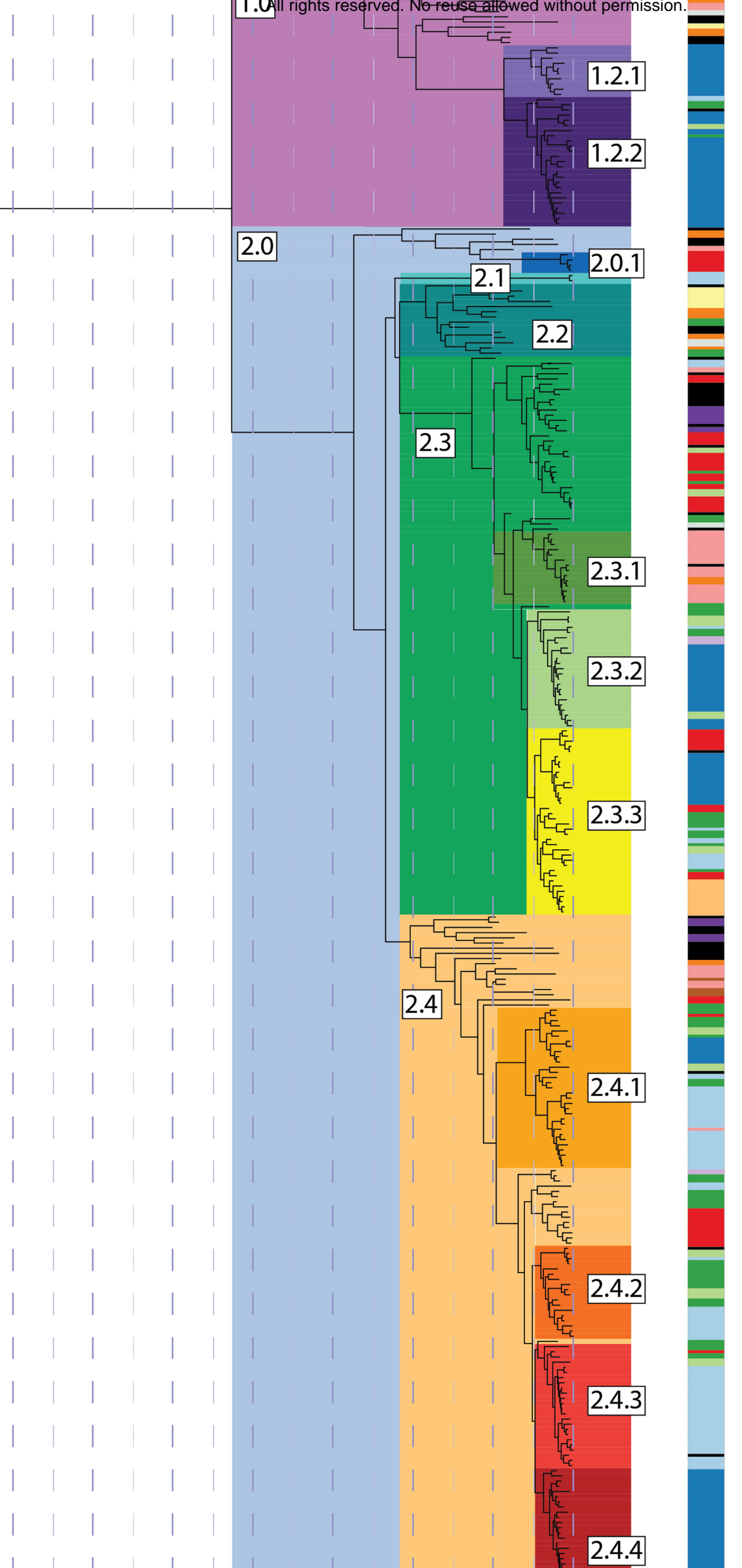

\section{Genotypes}

$\square 0.1 \square 2.3$

$\square 1.0 \square 2.3 .1$

$\square 1.1 \quad \square 2.3 .2$

$\square 1.2 .1 \square 2.3 .3$

$\square 1.2 .2 \square 2.4$

$\square 2.0 \quad \square 2.4 .1$

$\square 2.0 .1 \quad \square 2.4 .2$

$\square 2.1 \square 2.4 .3$

$\square 2.2 \square 2.4 .4$

\section{Country ( $\geq 5$ isolates)}

Bangladesh

$\square$ India

$\square$ Nepal

$\square$ UK

$\square$ Cambodia

Pakistan

$\square$ China

$\square$ France

$\square$ Myanmar

- Senegal

$\square$ Morocco

Indonesia

$\square$ Turkey

- Others 
medRxiv preprint doi: https://doi.org/10.1101/2021.11.13.21266165; this version posted November 28, 2021. The copyright holder for this preprint (which was not certified by peer review) is the author/funder, who has granted medRxiv a license to display the preprint in perpetuity All rights reserved. No reuse allowed without permission.

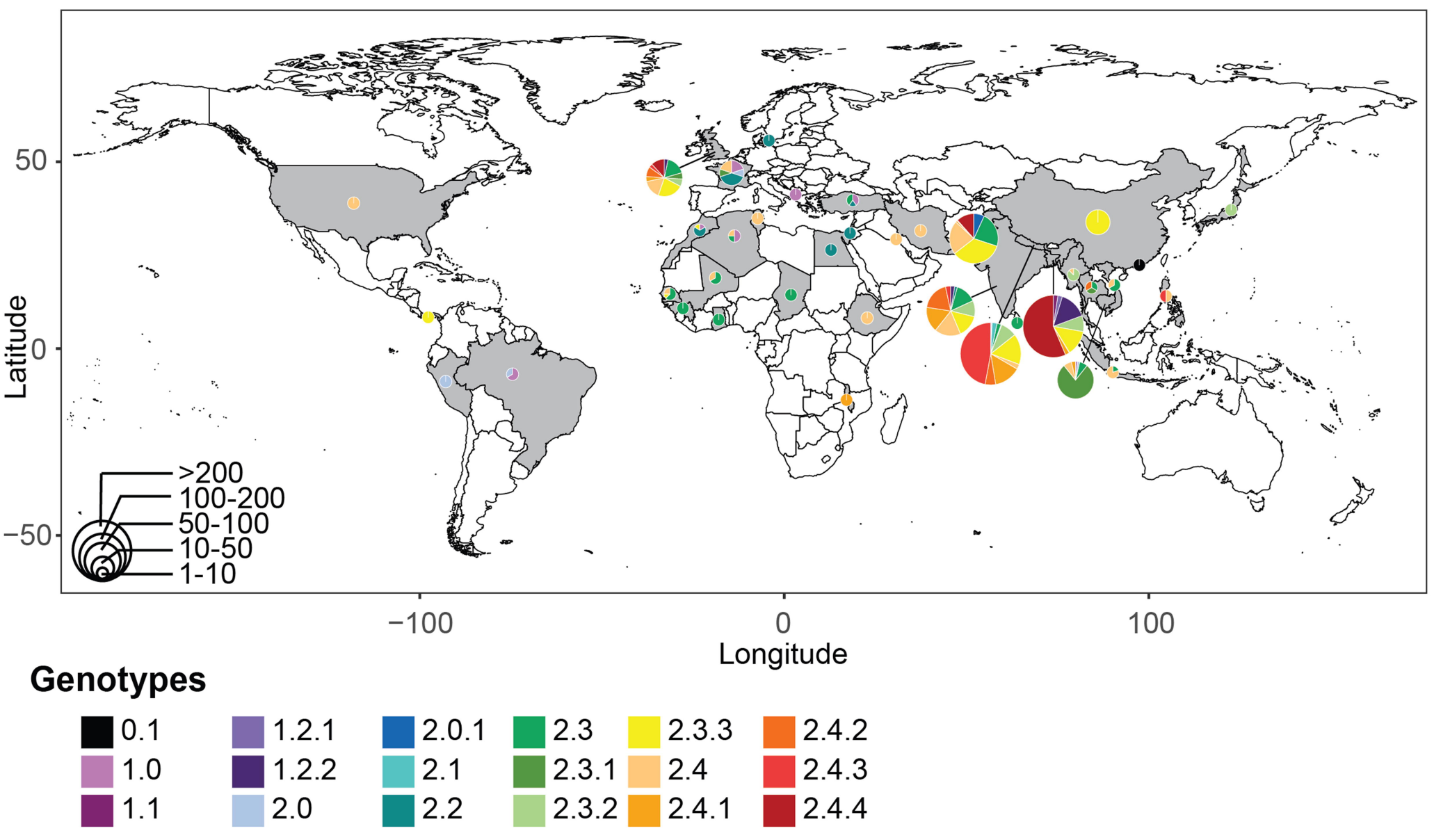


medRxiv preprint doi10tex-4/doi.org/10.1101/2021.11.1321266165; this version posted November 28 2021. The-copyright holder for this preprint (which was not certified by peer review) is the author/funder, who has granted medRxiv a license to display the preprint in perpetuity.

a

Resistant genes

blaCTX-M-15, blaTEM-1B blaTEM-116

blaTEM-1B,catA1,sul1,sul2 tet(B),dfrA7

catA1

catA1,sul1,sul2,tet(B),dfrA7

qnrB19

sul2

No resistant genes

b

\section{Plasmids}

Col(BS512)

Col(pHAD28)

ColpVC

CoIRNAI

IncFIB(pHCM2)

IncFIB(pHCM2), Col(pHAD28)

IncFIB(pHCM2), IncX1 Col(pHAD28)

IncFII

IncHI1

Incl1-I

IncQ1,IncHI1

$\operatorname{IncX1}$

IncX1,ColpVC

No plasmids

C

\section{QRDR mutations}

gyrA-D87G

gyrA-D87N

gyrA-D87Y

gyrA-S83F

gyrA-S83F, gyrA-D87G

gyrA-S83F, gyrA-D87N

gyrA-S83Y

No mutations
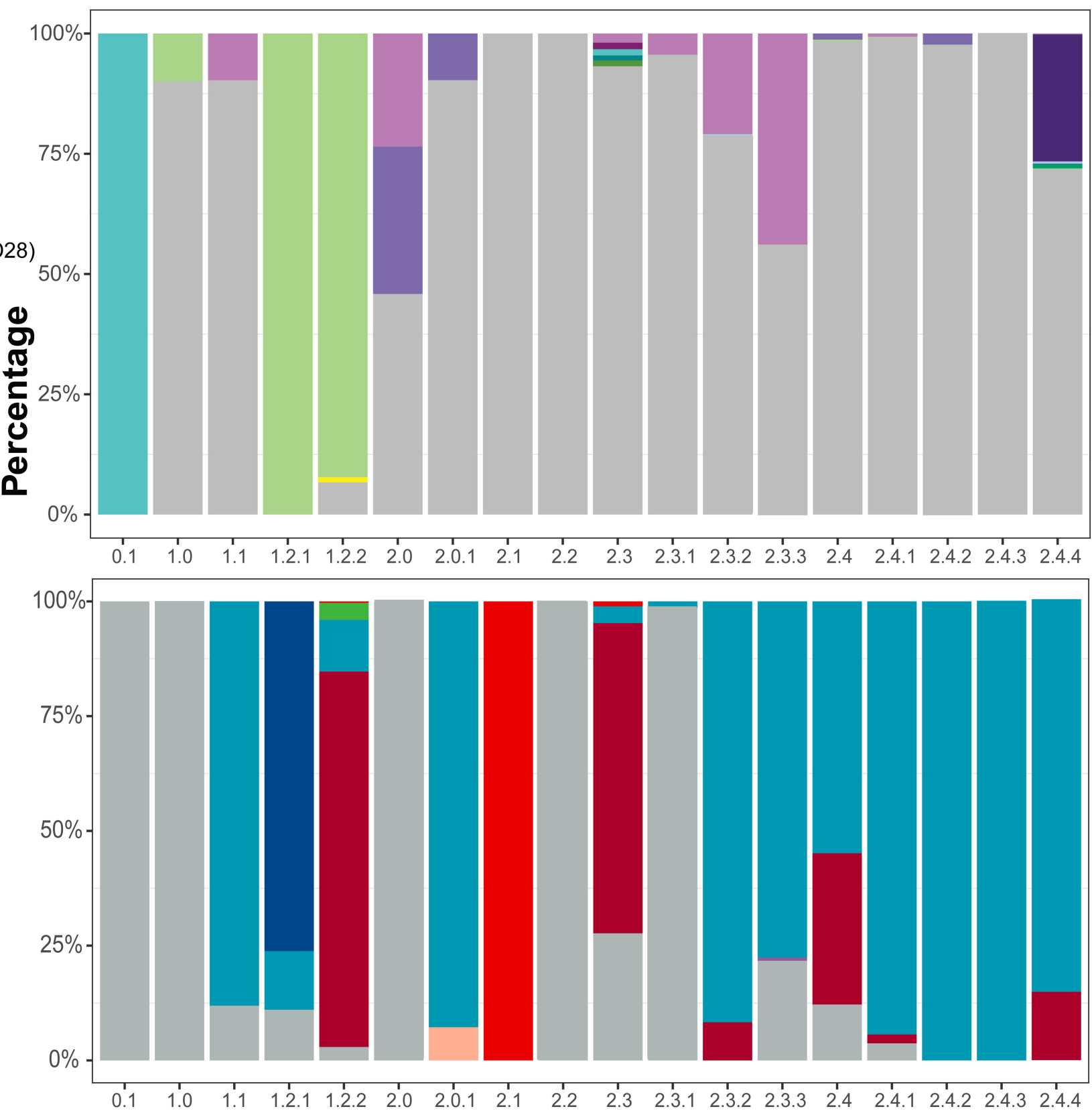